\title{
Mapping Analysis Distribution of Microplascticat the Tallo River in Macassart
}

\author{
Alfina Baharuddin', Muhammad Ikhtiar', A. Rizki Syamsul Bahri ${ }^{2}$ \\ ${ }^{1}$ Lecturer Departement of Environmental Health, Public Health University, Moslem of Indonesia, \\ ${ }^{2}$ Postgraduated program Magister of Public health University Moslem of Indonesia
}

\begin{abstract}
This aims of the study to identify spatial microsplastic pollution sediments in the Tallo River Makassar City. This type of research is descriptive observational. This research design uses a Geographical Information System (GIS) Statistical analysis using the average abundance of microplastics is presented in tables and graphs, then analyzed descriptively quantitatively at each station. Data showing the mean \pm standard deviation were analyzed using SPSS software. Based on the results of research that has been done, the number of microplastics found in the sediments in the Tallo River is 289. The highest microplastic size found in the Tallo River sediments is $1.00-4.75 \mathrm{~mm}$ as much as $167 \mathrm{MP}(58 \%)$ with an average abundance of $18,56 \pm 30,875 \mathrm{MP} / \mathrm{kg}$. Followed by a size of $<1 \mathrm{~mm}$ as much as $112 \mathrm{MP}(39 \%)$ with an average abundance of microplastics $12.44 \pm 17.686 \mathrm{MP} / \mathrm{kg}$ and sizes $>4.75 \mathrm{~mm}$ as much as $10 \mathrm{MP}(3 \%)$ with an average abundance of microplastics $1.11 \pm 2,315 \mathrm{MP} / \mathrm{kg}$.
\end{abstract}

Keyword: Mapping, Microplastic, sediment, river.

\section{Introduction}

One of the results of environmental pollution is the accumulation of garbage. Waste production in Makassar City in 2018 was 1,261 tonnes/day (World Bank Group, 2018). This results in garbage entering the river body and ending up in the marine environment. The type of waste that dominates in the waters is plastic waste ${ }^{1}$. In 2019 , plastic contributed $60 \%-80 \%$ of waste in the sea and is a threat to the ecosystem. Plastics that are degraded to MP $<5 \mathrm{~mm}$ in size known as microplastics can accumulate in sediments and are consumed by marine organisms ${ }^{2,3,4}$.

The highest concentration of microplastics is found in the estuaries of many rivers. Population density, domestic discharge, industrial disposal and urban activities can be a contributor to microplastic pollution in sediments. Wind and currents also act as drivers for the distribution of microplastics. Coastal currents and

\footnotetext{
Coressponding Author:

Alfina Baharuddin

Lecturer Departement of Environmental Health, Public

Health University, Moslem of Indonesia

e-mail: alfina.bahruddin@umi.ac.id
}

wind transport can contribute to a higher distribution of microplastics at river mouths and adjacent to shore. Lack of proper plastics management could be a cause of transport and the relatively high abundance of microplastics in river estuaries ${ }^{5,6,7}$.

Microplastics are susceptible to sedimentation as evidenced by differences in the type and shape of the polymer. Microplastic size decreases with increasing microplastic concentration in water and sediment. smallmicroplastic particles will take more time to settle than larger ones. Adverse human health impacts from the consumption of micro and nanoplastics in seafood can be caused by the plastic particles themselves or the inherent additives and contaminants such as Persistent, Bioaccumulative, and Toxic Substances (PBTs). Microplastic intake in humans from seafood has been estimated at 1 particle per day to 30 particles per day depending on seafood consumption habits and the organism's exposure to microplastics ${ }^{8,9}$.

Microplastics contain a mixture of chemicals added during the manufacture of plastics which can become contaminated in the environment. These chemical additives include monomers, oligomers, plasticizers, and flame retardants. Meanwhile, contaminants that are 
absorbed from the environment include Polychlorinated Biphenyls (PCBs), Polycyclic Aromatic Hydrocarbons (PAHs), Chlorinated Pesticides, and the Persistent Organic Pollutants (POPs) group. Persistent Organic Pollutants (POP) are classified as Bioaccumulative Toxic Substances (PBTs) which have the ability to accumulate in organisms ${ }^{10,11}$.

One of the studies conducted stated that domestic discharge, surface runoff, municipal discharge and factory effluent were identified as important contributors to microplastic pollution in sediments. In addition, wind and currents are other drivers in the distribution of microplastics along river flows ${ }^{12,13}$. This study is consistent with the research that has been found that microplastics are found in the most sediments in the 2.45 and 4.75 size categories because they are influenced by their mass. A similar study was also conducted by Karthik, et.al. (2018), that among all classes, the MP size of microplastics between 1.18 and $2.36 \mathrm{~mm}$ shows the highest microplastic abundance in sediments in Indian waters $^{2,4,15}$.

Effluent without proper treatment from Wastewater Treatment Plants significantly increases the abundance of microplastics in water and sediment. In addition, the activities of the plastics industry directly contribute to the load of microplastics downstream and water bodies. Recreational activities along the river contribute a large amount of plastic waste which is a direct source of microplastic ${ }^{11,14,16 .}$

Tallo River is surrounded by rice fields, fishponds and some residential areas. In addition, along the Tallo River, there are several industries including Steam Power Plant (PLTU). The Tallo River is used as a disposal site for used cooling water, a carrier for industrial waste from households to the sea and as a means of transportation for fishermen, fishpond farmers and industry (Zainal and Awaluddin, 2018). Tallo River is used as a means of transportation and tourism activities, namely mangrove nature tourism, Lakkang tourism village, TirtaBugis Waterpark tourism, M; Tos shopping center, and historical tours of the tombs of the Tallo Kings. Based on this background, the researcher is interested in researching microplastic identification in the sediments in the Telloriver, Makassar city.

\section{Method}

This type of research is descriptive observational. This research design uses a Geographical Information Systems (GIS) approach. Collecting data using the exploratory method, namely direct sampling. The research was carried out in the Tallo City River in 2020.

The materials used for testing the sediment samples were sediment, $\mathrm{NaCl}$ solution, Aquabidest, aluminum foil, $47 \mathrm{~mm}$ Whatman Nitrocellulose filter paper, plastic samples, and label paper. Sediment sampling was carried out using a shovel with a depth of $3 \mathrm{~cm}$. The sediment was then put into the plastic sample as much as $1 \mathrm{~kg}$.

Separation of microplastic particles from sediment is carried out in several steps, namely:

(a) Drying was carried out in an oven at $75 \mathrm{oC}$ until the water content of the sediment ran out.

(b) Reduction of the volume of dry sediment was carried out by sieving (size $5 \mathrm{~mm}$ ). The sieve sample was put into an Erlenmeyer flask.

(c) Density separation was carried out by mixing a 100 gram dry sediment sample and a saturated $\mathrm{NaCl}$ solution (300 gr NaCl +1 liter Aquabidest) with an estimate of 3 times the sample volume. Then the mixture was stirred using a Shaker Rotator H-SR200 for 2 minutes. The sample is then left for 12 hours to form a supernatant.

(d) Filtering was done by filtering the supernatant using Whatman Nitrocellulose $47 \mathrm{~mm}$ with the aid of a vacuum pump.

(e) Visual sorting. Microplastic particles were sorted visually using a stereo microscope and microplastic observations were made.

\section{Result}

The proportion of the number of microplastics contained in the sediment samples at each station is as follows. 


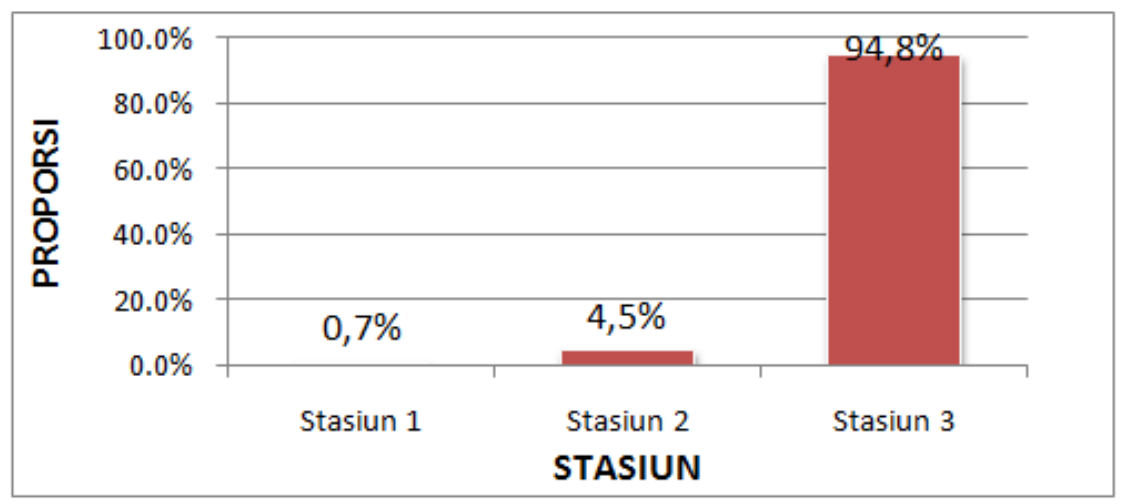

Figure 1 Proportion of Microplastic Data in the Sediment

Based on Figure 1 shows, the proportion of the number of microplastics in the sediment at station 1 is $0.7 \%$, station 2 is $4.5 \%$, and at station 3 is $94.8 \%$.

The proportion of the amount of microplastic contained in the sediment sample is based on its shape as follows.

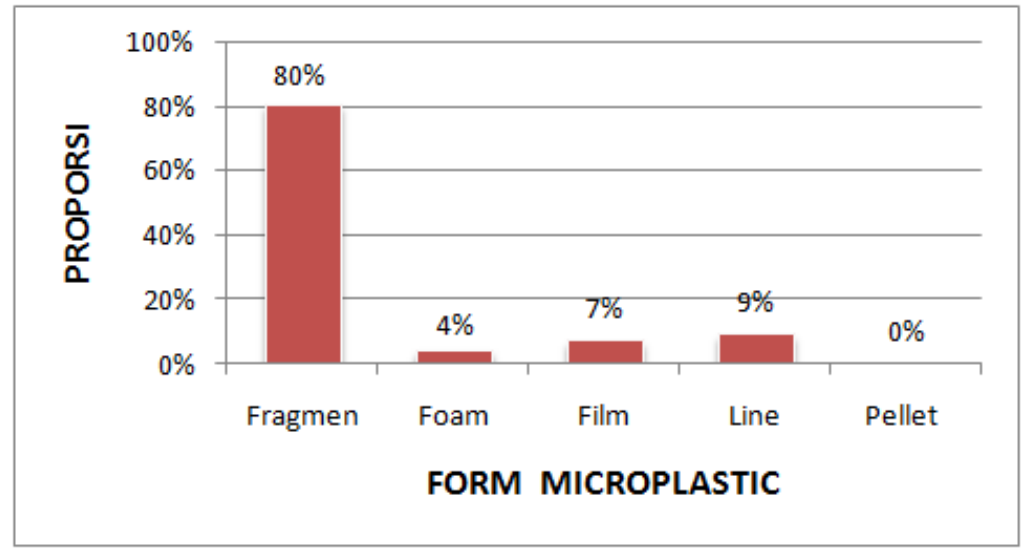

Figure 2 Proportion Data of the Amount of Microplastic in the Sediment

Based on Figure 2, the proportion of the amount of microplastics in the sediment in the Tallo River based on its shape is $80 \%$ fragment shape, $4 \%$ foam, $7 \%$ film and $9 \%$ line.

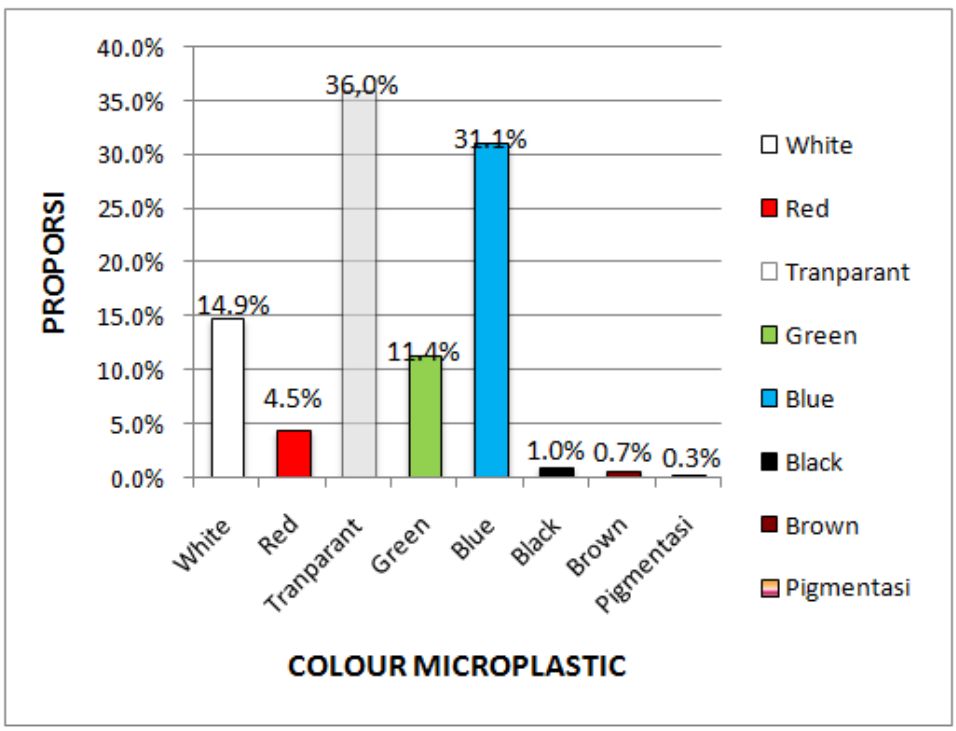

Figure 3 Proportion of the Amount of Microplastic in the Sediment 
Based on Figure 3 shows that the proportion of the amount of microplastic in the sediment in the Tallo River based on its color is white $14.9 \%$, red $4.5 \%$, transparent $36.0 \%$, green $11.4 \%$, blue $31.1 \%$, black color $1.0 \%, 0.7 \%$ brown color, and $0.3 \%$ pigmented color.

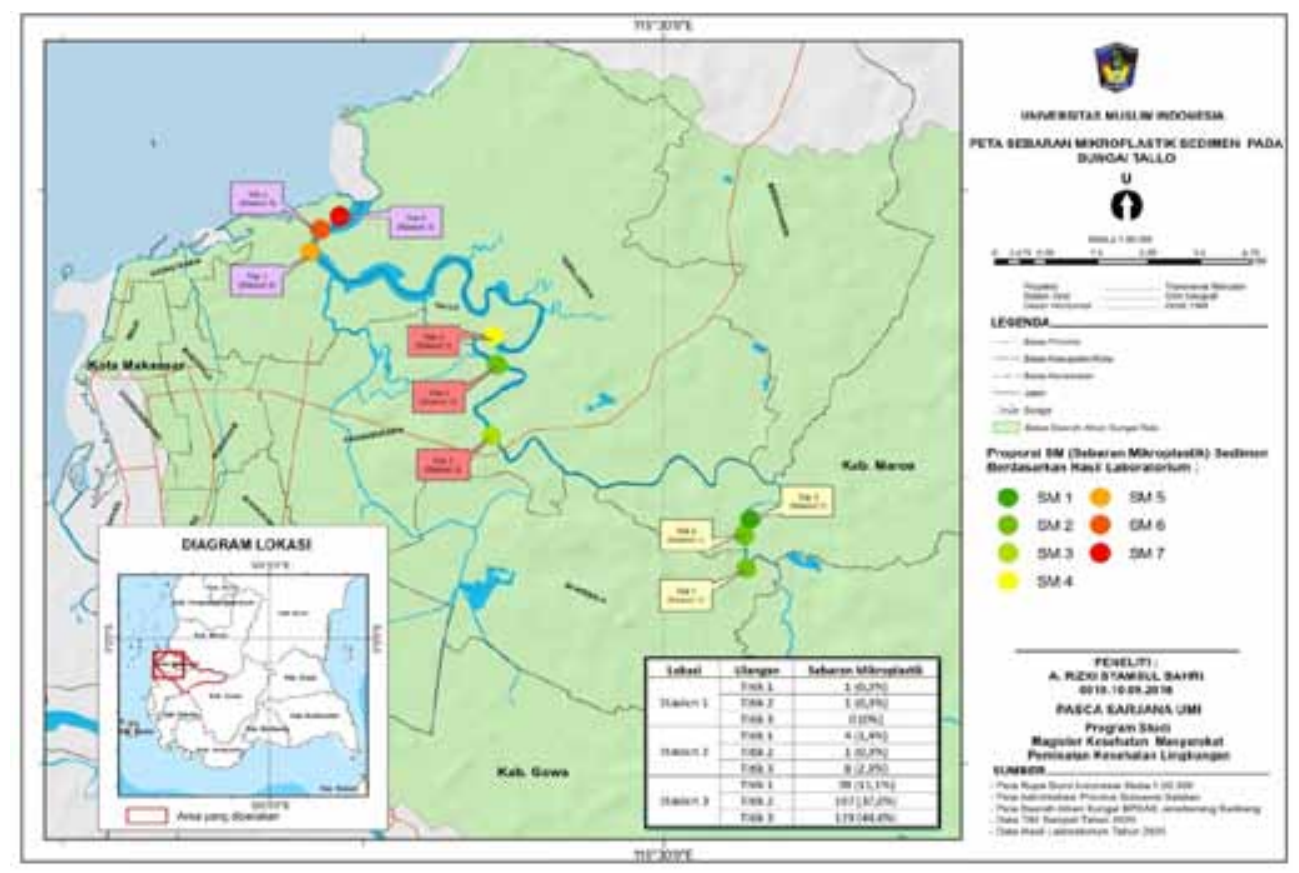

Gambar 3 Distribusi Pencemaran Mikroplastikpada Sedimen di Sungai Tallo

Based on Figure 3, it shows the distribution of microplastic pollution in the sediments in the Tallo River, namely at station 1 point 1 as much as $1 \mathrm{MP}$ $(0.3 \%)$, point 2 as much as $1 \mathrm{MP}(0.3 \%)$ and point 3 microplastics are not found. As for station 2, point 1 is $4 \mathrm{MP}(1.4 \%)$, point 2 is $1 \mathrm{MP}(0.3 \%)$ and point 3 is 8 MP (2.8\%). Meanwhile, at station 3, point 1 is $38 \mathrm{MP}$ (13.1\%), point 2 is $107 \mathrm{MP}(37 \%)$ and point 3 is $129 \mathrm{MP}$ (44.6\%).

\section{Discussion}

Based on the research results, the forms of microplastics found in sediments are fragments, foam, film, and line. The shape of the fragments is a form that is found more in the Tallo River compared to other forms, namely as much as $231 \mathrm{MP}(80 \%)$ with an average abundance of microplastics $25.67 \pm 40.811 \mathrm{MP} / \mathrm{kg}$.

This study is in accordance with the research microplastics found around Kupang and Rote are dominated by fragments. Fragments are pieces of plastic that have strong synthetic polymers such as drinking bottles and other plastic food packaging.. That fragments contribute to the majority of microplastics in sediments and are followed by line shapes both at high tide and at low tide. The distribution of the size and shape of the microplastics in the sediments can be caused by various factors such as the source of the plastic, the quality of the debris, the degradation of macroplastics, the wind currents and the sinking rate of the plastics and the relative susceptibility to microbes $2,6,17,18$.

Fragment microplastics are microplastics that come from anthropogenic activities such as household waste. Fragments can come from bottles, plastic bags and pieces of pipe pipe. Fiber microplastics come from synthetic fabrics, fishing boat waste and fishing gear such as fishing nets and fishing lines. This type of fiber can also be called a line. This type of film comes from food packaging Meanwhile, fragments came from large plastic fractures. Fragments are microplastics derived from pieces of plastic products with strong synthetic polymers. Fiber or line comes from washing clothes, namely the residue of clothing yarn and plastic rope that is degraded and is also affected by fishing activities that come from fishing rods and nets. Films are microplastics that come from the cut and degrade of plastic bags ${ }^{10,19,20}$.

Although foam forms have a lower number than fragments, lines and films, this shape also needs attention. A special structure with many cavities in it and is often 
used for sound insulation, heat insulation and impact avoidance. This foam is widely used in packaging, auto components, clothing, and building equipment. Its brittle nature and low density make it easier to enter and float in water. The results of identification in this study, the color of the microplastics found in the Tallo River sediments are white, red, transparent, green, blue, black, brown and the color of the pigmentation results. The most dominant plastic color in the Ofanto River is transparent (56\%), followed by black (35\%). Microplastics can inherit color from the parent plastic product, but the color can change due to photodegradation and residence time in water. This shows the degree of fragmentation. Microplastic with a transparent color is the initial identification of the type of Polypropylene (PP) polymer and indicates the length of time the microplastic has been photodegradable by UV light. The black color can indicate the amount of contaminants absorbed in the microplastic and has the ability to absorb high pollutants which can affect the texture of the microplastic ${ }^{9,14,18 .}$

The high level of microplastics in the sediments illustrates that the microplastics originating from land are also high. In this study, the sediment sampling was carried out at three points per station. Based on the research results, at station 1 point 1 and point 2 it was found that each $1 \mathrm{MP}(0.3 \%)$. Community activities at points 1 and 2 are still insufficient and far from residential areas. At point 1 is the Nipa-Nipa Regulated Reservoir Gazebo where the existing activities are only fishing activities for the surrounding community. Point 2 is to the east of the Nipa-Nipa Sewage Treatment Plant, which is under the Nipa-Nipa intersection. At this location it is still far from activities and residential areas. Whereas point 3 is a location very far from residential areas and is in the middle of a very large agricultural land. So that no microplastics are found at point 3 because there is no

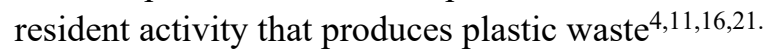

The high level of microplastics in the sediments illustrates that the microplastics originating from land are also high. In this study, the sediment sampling was carried out at three points per station. Based on the research results, at station 1 point 1 and point 2 it was found that each $1 \mathrm{MP}(0.3 \%)$. Community activities at points 1 and 2 are still insufficient and far from residential areas. At point 1 is the Nipa-Nipa Regulated Reservoir Gazebo where the existing activities are only fishing activities for the surrounding community. Point 2 is to the east of the Nipa-Nipa Sewage Treatment Plant, which is under the Nipa-Nipa intersection. At this location it is still far from activities and residential areas. Whereas point 3 is a location very far from residential areas and is in the middle of a very large agricultural land. So that no microplastics are found at point 3 because there is no resident activity that produces plastic waste ${ }^{8,22}$.

At station 2 point 1, 4 MP (1.4\%) was found which came from anthropogenic waste. Point 1 is located in a residential area so that the resulting waste is the result of resident activities. At point 2 it is found that $1 \mathrm{MP}(0.3 \%)$ is lower than point 1 . This is because the sampling location in point 2 is a location far from residential areas. The activities around point 2 are fishing activities and river transportation.Meanwhile, at point 3, Lakkang Island, the number of microplastics is higher than points 1 and 2, namely $8 \mathrm{MP}(2.8 \%)$. This is due to the confluence of the pampang tributaries and tributaries of PT. KIMA so that plastic waste accumulates at point 3. In addition, Lakkang Island is a residential location that does not have a Final Disposal Site (TPA) so that the resulting waste is dumped directly into the river.

\section{Conclution}

The number of microplastics found in sediments in the Tallo River was 289 particles. The microplastic forms identified were fragment, foam, film and line. The colors of microplastics identified were white, red, transparent, green, blue, black, brown and pigmented colors. The microplastic sizes identified were $<1 \mathrm{~mm}$ and $1.00-4.75 \mathrm{~mm}$ and $>4.75 \mathrm{~mm}$.

Source of Funding: Self-funding

Conflict of Interest: None of the authors has competing interests

Ethical Clearance: Taken from Comitee ethical Clearences of Universitas Muslim of Indonesia Makassar

\section{References}

1. Wilson, J.R., Saunders, R.J. and Hutson, K.S., Parasites of the invasive tilapia Oreochromismossambicus: evidence for cointroduction. Aquatic Invasions, 14, pp.332349,2019 .

2. Yudhantari, C.I., Hendrawan, I.G. and Ria Puspitha, N.L.P.,. Kandungan Mikroplastikpada Saluran Pencernaan Ikan Lemuru Protolan (SardinellaLemuru) HasilTangkapan di Selat Bali. Journal of Marine Research and Technology, 2(2), 
p.48.Along The Coast of Grandola, Portugal. Sustainable Coastal Management.2019.

3. Datu, S.S., Supriadi, S. and Tahir, A., Microplastic in Cymodocearotundata Seagrass Blades. International Journal of Environment, Agriculture and Biotechnology, 5(6).2019

4. Hastuti, A.R., Lumbanbatu, D.T. And Wardiatno, Y., The presence of microplastics in the digestive tract of commercial fishes of Pantai Indah Kapuk coast, Jakarta, Indonesia. Biodiversitas Journal of Biological Diversity, 20(5).019.

5. Joesidawati, M.I., Pencemaranmikroplastik di sepanjangpantaikabupaten Tuban. In Prosiding Seminar Nasional Hasil Penelitian Dan Pengabdian Kepada Masyarakat III Universitas PGRI Ronggolawe (pp. 8-15). 2018.

6. Herath, H.M.T.N.B., Radampola, K. and Herath, S.S., Morphological Variation And Length Weight Relationship of Oreochromismossambicus in Three Brackish Water Systems Of Southern Sri Lanka. International Journal of Research, 2(2), pp.23112476. 2014.

7. Lopes, C., Raimundo, J., Caetano, M. and Garrido, S., Microplastic ingestion and diet composition of planktivorous fish. Limnology and Oceanography Letters, 5(1), pp.103-112.2020.

8. Purba, N.P., dkk. Sebaranspasialmikroplastik di sedimen Pantai Pangandaraan, Jawa Barat. JurnalGeomaritim Indonesia (Indonesian Journal of Geomaritime), 1(1), p.1.2018.

9. Sari, C.N., Zuhrawati, N.A. And Asmilia, N., Profil Hematologi Ikan Mujair (Oreochromis Mossambicus) Yang Terpapar Merkuri Klorida (Hgcl2) [The Profile of Tilapia Fish (OreochromisMossambicus) Hematology Expose To Mercury Chloride (Hgcl2)]. Jurnalllmiah Mahasiswa Veteriner, 1(3), Pp.439-447. 2017

10. Cordova, M.R. and Hernawan, U.E., June. Microplastics in Sumba waters, East Nusa Tenggara. In IOP Conference Series: Earth and Environmental Science (Vol. 162, No. 1, p. 012023). IOP Publishing, 2018.

11. Cox, K. Distribution, Abundance, and Spatial Variability of Microplastic Pollution in Surface Waters of Lake. Master of Environmental Studies, Social and Ecological Sustainability. 2018.

12. Mauludy, M.S.,Yunanto, A. and Yona, D. Microplastic Abundances in the Sediment of Coastal Beaches in Badung, Bali. Jurnal Perikanan
Universitas Gadjah Mada, 21(2), pp.73-78. 2018.

13. Tahir, A., et.al. Microplastics in Water, Sediment and Salts from Traditional Salt Producing Ponds. Department of Marine Science, UniversitasHasanuddin, Makassar, Indonesia. 2019.

14. Mawaddha, R. and Firdaus, A.T., Studies of Micro Plastics contamination on mussels, seawater, and sediment at Sanrobengi Island of South Sulawesi. Advances in Environmental Biology, 14(2), pp.1218. 2020.

15. Karrman, A., et.al. Exposure and Effect of Microplastics on Wildlife. Swedish Environmental Protection Agency, School of Science and Technology, Orebro University, Sweden. 2016.

16. Lusher, A., et.al. 2017. Testing of methodology for measuring microplastics in blue mussels (Mytilusspp) and sediments, and recommendations for future monitoring of microplastics ( $\mathrm{R} \&$ D-project). Norwegian Institute for Water Research..2017.

17. Menéndez-Pedriza, A. and Jaumot, J., 2020. Interaction of Environmental Pollutants with Microplastics: A Critical Review of Sorption Factors, Bioaccumulation and Ecotoxicological Effects. Toxics, 8(2), p.40.

18. Karthik, R., Robin, R.S., Purvaja, R., Ganguly, D., Anandavelu, I., Raghuraman, R., Hariharan, G., Ramakrishna, A. and Ramesh, R., Microplastics along the beaches of southeast coast of India. Science of The Total Environment, 645, pp.13881399. 2018.

19. WHO. Microplastics in Drinking-Water. World Health Organization. 2019.

20. Wicaksono, E.A., Tahir, A. and Werorilangi, S., Preliminary study on microplastic pollution in surface-water at Tallo and Jeneberang Estuary, Makassar, Indonesia. Aquaculture, Aquarium, Conservation \& Legislation, 13(2), pp.902-909. 2020.

21. Dewa, M.I., Analisis Karakteristik Model Spasial di Kabupaten Gowa Berbasis GIS dan Remote Sensing Menggunakan Citra Landsa. 2017.

22. Diyanti, Kamila. Biota LautsebagaiSumber Ide Pembuatan Cenderamata Logam Wisata Pantai Pasir Putih Kabupaten Situbondo. Pendidikan Seni Rupa, Fakultas Bahasadan Seni, Universitas Negeri Surabaya. 2018. 